\title{
Obituary
}

\section{Dr T. H. C. Taylor}

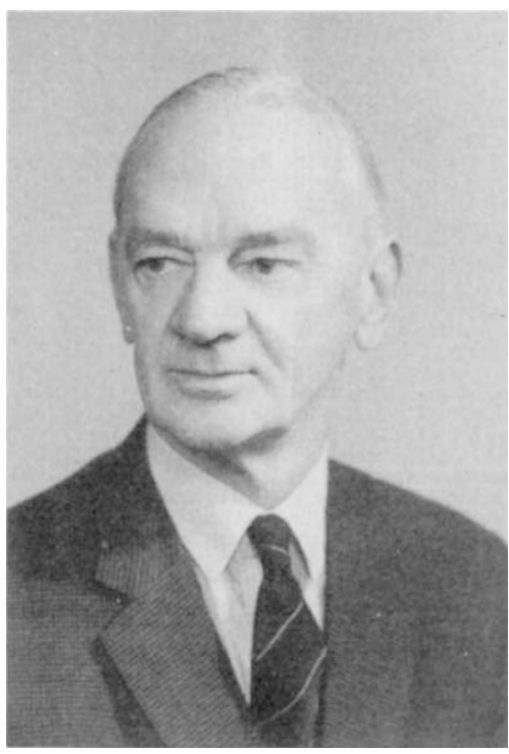

Dr Thomas Hugh Colebrook Taylor, who died on April 14, 1972, was a leading tropical entomologist and a pioneer of the biological control of insects. Starting in 1925 with the control of the coconut moth (Levuana iridescens) in Fiji by the introduction of the Malaysian fly parasite (Bessa remota), Taylor subsequently established the eulophid wasp (Pediobius parvulus) in the islands to control the coconut leaf-miner, and the coocinellid beetle (Cryptognatha nodiceps) to control the coconut scale insect, introductions which effectively controlled these serious pests. $\mathrm{He}$ also made early studies in Trinidad of a thrips (Liothrips urichi) which he used later in Fiji to control successfully the pasture weed (Clidemia hirta). The success derived from the introduction of four such unrelated predator and parasitic insects was largely due to Taylor's skilful field studies and captivity breeding techniques. His book, The Biological Control of an Insect in Fiji, made an important contribution to establishing biological control as a possible alternative to the use of insecticides; the method had been pioneered earlier in California and Hawaii and is of considerable interest nowadays with grow. ing public concern over the effect of insecticides on the environment. In a paper for the Jubilee Proceedings of the Association of Applied Biologists in 1935 Taylor expressed the view that biological control seldom works in continental areas and that the method was incompatible with the use of chemicals. This assessment at the time seemed a correct one, but it met with criticism which has to some extent proved justified owing to techniques developed in the last decades.

T. H. C. Taylor was born in 1901 at Ipswich, and graduated in 1924 with first class honours in zoology in the University of London from what was then University College, Reading. He went straight to Fiji to work on biological control, and in the course of his work travelled widely in Melanesia, Eastern Asia and the West Indies collecting suitable parasites, during which time he became familiar with a wide spectrum of the problems of tropical entomology.

In 1935 Taylor was transferred to Uganda as government entomologist at Kawanda Research Station, where he is still remembered with affection and respect for his work on cotton and coffee pests and their natural enemies. He was awarded a DSc degree in 1937 for work on biological control and in 1944 he returned to England to join the Commonwealth Institute of Entomology and became assistant director in 1946. Here his considerable literary talent was deployed to advantage in the field of scientific publications and his skill as an editor was much in demand.

In 1953, at the invitation of Sir Boris Uvarov, he joined the Anti-Locust Research Centre as deputy director and in 1959 succeeded Uvarov as director. Taylor's tenure of this office was marked by an enlargement of the scope and functions of the centre, already regarded as the main international body for locust research. He travelled widely, especially in Africa, and played a particularly important role in guiding the policies of newly independent countries in the sphere of locust control and research. As technical consultant to the UN Food and Agriculture Organization and to all the major international locust control organizations, Taylor worked hard to promote international cooperation in locust and grasshopper work and his tact, wisdom and knowledge were invaluable in facilitating compromise between the sometimes conflicting demands of science and politics. $\mathrm{He}$ was also concerned to promote more overseas work in the Anti-Locust Research Centre and in 1961 when the centre became one of the scientific units of the new Department for Technical Cooperation - now the Overseas Development Administration of the Foreign and Commonwealth Office-he brought about the formation of a new group of locust scientists especially recruited for work abroad.

He played an active role in the work of several learned societies, notably the Association of Applied Biologists and the Royal Entomological Society of London, serving on the council of the latter from 1949 to 1951 . He was also a Fellow of the Institute of Biology.

Taylor's premature retirement in 1962 due to increasing ill-health was a sad blow to the centre and to entomo$\operatorname{logy}$ as a whole, but luckily for the former he remained on the staff as editor, where he zealously guarded the extremely high standards of scientific publication which he had set while director. Hie also acted as a technical editor for the Food and Agriculture Organization of the United Nations and largely due to his efforts such mammoth reports as that of UNDP/ FAO Desert Locust Project, covering eight years of international research on the desert locust, became valuable and readable publications.

Taylor, or "Taggers" as he was known to many generations of entomologists, was in the best and truest senses of the words both a gentleman and a scientist; kindness, courtesy and consideration were part of his nature and these, allied to his foresight and wide knowledge of tropical entomology, enabled him to guide, counsel and assist on problems scientific, organizational and personal, with a skill and tact which were as unobtrusive as they were effective.

\section{Announcements}

\section{Miscellaneous}

Dr John W. Boag, Institute of Cancer Research, Sutton, has been awarded the L. H. Gray medal by the International Commission on Radiation Units and Measurements.

The 1972 A. A. Benedetti-Pichler award has been made to Professor Lyman C. Craig, Rockfeller University, for his work in microchemistry.

Beit Memorial junior fellowships for medical research have been awarded to S. R. Bloom, N. J. Brewin, D. A. East, R. T. Hunt, J. B. Wakerley, I. H. Maxwell, and R. Shields.

The Laboratoire de Biochimie du Tissu Conjonctif, Equipe de Recherche du 